\title{
Grey Forecasting of Inbound Tourism to Bali and Financial Loses from the COVID-19
}

\author{
Irsyad Yoga Laksito ${ }^{1, *} \mid$ I Gede Agus Yudiarta ${ }^{1}$ \\ ${ }^{1}$ Binjiang College of Nanjing University of Information Science and Technology, Wuxi, China \\ *Corresponding author: irsyadyogal@gmail.com
}

Received 3 June 2021; Revised 5 July 2021; Accepted 6 July 2021

\begin{abstract}
Management and planning in the Indonesian tourism industry is an important matter. It involves responding to changes and uncertain conditions, especially in the tourism industry sector in Bali, Indonesia. Bali is a tourist spot that relies on foreign tourists. When a situation is not conducive, such as the COVID-19 outbreak that befell unexpectedly, proper management and planning are challenging without accurate forecasts. The current study used the Even Grey Forecasting model EGM $(1,1, \alpha, \theta)$ to forecast the number of tourists to Bali, a famous tourist spot in Indonesia, and the approximate financial loss incurred from the pandemic in 2020 is quantified. These objectives are achieved through the data collected from the Bali statistical agency and analyzed through the grey model and some mathematical computations. The results indicated that the pandemic's impact on inbound tourism was severe, and the economy needs some time to recover. The study reported a loss of more than $\$ 7.3$ billion to Bali due to the COVID-19 outbreak. It is possibly the first study of its kind, and its findings are important for the policymakers, Tour \& Travel service providers, and tourism-related businesses.
\end{abstract}

Keywords: Tourism; Bali Indonesia; Grey Forecasting; Financial Loss; COVID-19

\section{Introduction}

Indonesia is one of the tourist destinations that are in great demand by foreign and domestic tourists. The tourism industry in Indonesia has shown sustainable growth both in income and in the number of tourists. One of the tourist destinations in great demand by foreign and domestic tourists in Indonesia is the island of Bali. Bali has succeeded in becoming a leading tourist destination in Indonesia since the late 1960s (Yamashita, 2012). The international event quoted from the travel media of the United States, namely Travel + Leisure in the Best Island Category in the World 2019, consists of 15 beautiful islands. The island of Bali is in third place this year, down one place from 2018, where Bali is in second (Silvita, 2019). Bali is also known for its unique and rich culture, cultural activities, and sites.

Tourism plays a critical role in Bali's economy. In the last few decades, this sector has shown a remarkable increase. The tourism industry also has enormous and diverse economic potential that can drive economic growth (Haryanto, 2020). Although the economy in the tourism industry continues to develop, there are also significant obstacles. Such as unexpected events or natural disasters that occur. Like in 2020, when the novel coronavirus (COVID-19) devastated Bali. As a result of the COVID-19 pandemic, Bali's economic performance in 2020 has experienced a sharp decline, as shown in Table 1. From the demand side, the decrease in the output of the Balinese economy is due more to the decline in foreign exports and government consumption. And the slowdown in household consumption growth. This situation is caused by the COVID-19 pandemic, forcing several countries to enforce and 
Table 1. Financial Report for the Province of Bali, 2019 to 2020 (Source: BI, 2021)

\begin{tabular}{|c|c|c|c|c|c|c|c|c|}
\hline \multirow{2}{*}{ Indicator } & \multicolumn{9}{|c|}{ 2019 } & \multicolumn{4}{|c|}{2020} & III & IV \\
\cline { 2 - 9 } & I & II & III & IV & I & II & III \\
\hline $\begin{array}{c}\text { Economic Growth } \\
\text { (\%, yoy) }\end{array}$ & 5.98 & 5.64 & 5.28 & 5.51 & -1.20 & -11.06 & -12.32 & -12.21 \\
\hline $\begin{array}{c}\text { Gross Regional } \\
\text { Domestic Product } \\
\text { (Rp. billion) }\end{array}$ & 39.085 & 40.258 & 41.509 & 41.843 & 38.614 & 35.807 & 36.393 & 36.735 \\
\hline
\end{tabular}

restrict travel strictly. As a result, the tourism industry, one of Bali's economic supports, was seriously affected as the number of tourists declines.

The COVID-19 outbreak was unexpected, and became one of the most significant things that ever happened to Bali's tourism industry (see Table 2). Its effect can be long-lasting. There is hardly any country or industry that is not affected by the pandemic (Irfan et al., 2021; Mahmoudi et al., 2020). Thus, the tourism industry of Indonesia is no exception. It can be said that the extent to which business actors can survive to keep the tourism industry going (Bhaskara \& Filimonau, 2021). However, studies about disaster management in tourism still lack due to disasters that rarely recur (Seraphin, 2019). The COVID 19 pandemic can be used as a lesson to prepare preparedness for factors that can affect the tourism business, which can provide lessons for considering future business planning and can be helpful in cases of disasters or crises that can reoccur (Ghaderi et al. 2015). This study examines the impact of COVID19 on the tourism business in Bali, a popular destination in Southeast Asia, one that has many foreign tourist arrivals.

The paper's structure is as follows: The first section is an introduction, which is followed by a section on literature review. This section discusses the tourism industry in Bali, the origins of COVID-19 in Bali, the Campaign for the cleanliness, health, safety, and environmental (CHSE) in Bali, and Grey forecasting theory. Later, we have a section on research methodology that describes the data collection strategy, all forecasting techniques that will be used, and the forecasting accuracy measurement method. All data obtained in the research methodology will be processed in the fourth section, producing forecasts of inbound tourism to Bali. Later, the approximate financial losses faced by Bali during the COVID-19 pandemic. From the research data, it can be concluded that the COVID-19 pandemic has

Table 2. Number of International Tourist Arrivals in Bali from 1997 to 2020 (Source: Putra, 2008; BPSPB, 2020)

\begin{tabular}{|l|c|c|}
\hline Year & Number of tourists & Important incident \\
\hline 1997 & $1,230,316$ & Rsian Economic Crisis \\
\hline 1998 & $1,187,153$ & \\
\hline 1999 & $1,355,799$ & Therm Movement \\
\hline 2000 & $1,376,839$ & Spread of SARS and bird flu \\
\hline 2001 & $1,356,774$ & The Second Bali Bombings \\
\hline 2002 & $1,285,844$ & \\
\hline 2003 & 994,616 & \\
\hline 2004 & $1,458,309$ & \\
\hline 2005 & $1,386,449$ & \\
\hline 2006 & $1,262,537$ & \\
\hline 2007 & $1,668,531$ & \\
\hline 2008 & $2,085,084$ & \\
\hline 2009 & $2,385,122$ & \\
\hline 2010 & $2,576,142$ & \\
\hline 2011 & $2,822,670$ & Agung Mountain Eruption \\
\hline 2012 & $2,949,332$ & \\
\hline 2013 & $3,278,598$ & \\
\hline 2014 & $3,766,638$ & \\
\hline 2015 & $4,001,835$ & \\
\hline 2016 & $4,297,937$ & \\
\hline 2017 & $5,697,739$ & \\
\hline 2018 & $6,070,473$ & \\
\hline 2019 & $6,275,210$ & \\
\hline 2020 & $1,069,473$ & \\
\hline & & \\
\hline & & \\
\hline
\end{tabular}


a significant impact on the number of tourists who come back. These things are explained in sections 5 and 6 , which contain conclusions and solve the problems that are currently happening.

\section{Literature Review}

\subsection{Tourism industry of Bali}

Bali is a popular tourist destination that can provide significant foreign exchange to Indonesia. The fast-growing tourism industry also influences Bali's contribution to economic growth. However, the tourism industry also has other factors that may disrupt the economy, such as natural disasters and other accidents. In the past, Bali has suffered several consecutive tragedies such as terrorist actions (Hitchcock \& Putra, 2005) and various natural disasters such as earthquakes and volcanic eruptions (Beirman, 2017). The results of this investigation can help the idea through) explaining how tourism businesses can quickly adapt to and recover from natural disasters and crises. This will add tourism management theory to be studied (Blackman et al., 2011). This study will examine how business players in the tourism industry in Bali must adapt to the current situation with proper management and planning to recover after being affected by the COVID-19 pandemic.

The literature emphasizes the need to know the types of hazards and crises that can trigger successive disasters when they impact business and develop preparedness and rapid response in disaster preparedness (Hall \& Prayag, 2020). The theory aims to learn about events and apply proper management and planning to prepare and restore business effectively and gradually. However, another idea shows that learning is not always proven and occurs (Filimonau \& De Coteau, 2020) because follow-up disasters or crises arise suddenly and are difficult to predict (Hall et al., 2016).

The COVID-19 epidemic in Bali, Indonesia, produced a lot of detrimental impacts on global tourism. Many people say that altering the present international tourism scenario needs all tourist companies to review their business models and then change operational behavior to reflect new government mandates and customer expectations (Hall et al., 2020). Being hit by natural disasters or incidents and crises is an interesting object of research. Experiences that occur several times in tourism destinations can provide learning and provide the skills needed to deal with disasters in the future (Jiang \& Ritchie, 2017), one of which is related to the impact of the COVID-19 pandemic. Past experiences, as mediated by learning, could inspire tourist firms to develop market strategies for planning events and dealing with future disasters and crises (Cioccio \& Michael, 2007). The 'correct' mix of talents and resources boosts industrial resilience (Faulkner, 2001). Every event that influences or is connected to the tourist sector can teach natural and human resources, allowing for learning in the tourism industry (Filimonau \& De Coteau, 2020).

\subsection{Bali during the COVID-19 pandemic}

The pandemic also hit the tourism sector hard. Until the end of 2020, a total of 743,198 patients had confirmed positive for COVID-19. The decline in local and foreign tourists also significantly impacted the economic road, especially in Bali, where the area relies heavily on local and foreign tourists. The data at the Indonesian statistics agency suggests that the decline during the pandemic year (2020) is significant. It can be seen from Table 3 that a very significant decline occurred the beginning of the COVID-19 pandemic that hit Indonesian tourist hot spots like Bali. In this case, the government has taken several steps to fight the COVID-19 pandemic. The government provided facilities and provisions that must be carried out in running a business in the tourism sector. Therefore, the tourism industry needs new management and planning in dealing with the economy in an arguably uncertain situation. There is also a need to learn from international best practices in this regard.

Table 3. The number of international tourist arrivals in Bali in 2020 (Source: BPSPB, 2020)

\begin{tabular}{|c|c|c|c|c|c|c|c|c|c|c|c|c|}
\hline Month & Jan & Feb & Mar & Apr & May & Jun & Jul & Aug & Sep & Oct & Nov & Dec \\
\hline $\begin{array}{c}\text { Number } \\
\text { of } \\
\text { Tourists }\end{array}$ & 536,611 & 364,639 & 167,461 & 379 & 36 & 45 & 16 & 12 & 8 & 63 & 53 & 150 \\
\hline
\end{tabular}




\subsection{Campaign for the Cleanliness, Health, Safety, and Environment (CHSE) in every tourist spot}

The Indonesian government has enforced a strict health protocol known as the "CHSE" (Cleanliness, Health, Safety, and Environment) in the tourism sector and creative economy in the country since September 2020 (Kemenparekraf, 2020). Under the Ministry of Tourism and Creative Economy, the CHSE provides opportunities for the tourism industry in Indonesia. Thus, a tourism industry such as Bali can conduct business and tourism by first obtaining a CHSE certification. Another goal of establishing the CHSE is to increase efforts to prevent and control COVID-19 in public places and facilities to avoid new epicenters or clusters during the pandemic.

CHSE has criteria that must be applied and implemented by every business entity in the tourism and creative economy sector. The essential thing in this regulation is Social Distance, which provides approximately 1 meter for each visitor when traveling in Bali. There are also masks that every tourist should wear. It is mandatory to wash your hands and use a hand sanitizer every time you enter or leave tourist attractions and every time you make a transaction. With the stipulated regulations, it is hoped that it can run and bring in visitors. Entrepreneurs in Bali must have excellent and proper management. First, they must provide the equipment and infrastructure to support CHSE regulation.

Dealing with virus spreaders and pandemics that occur suddenly is not an easy thing. It requires mature methods and strategies as well as the right skills in dealing with them. By maintaining and using the correct planning, the economy in the tourism industry, especially in Bali, can recover or even develop. In this case, several things must be applied.

\subsection{Grey Forecasting}

Forecasting future developments has always been important in various fields, one of which is the tourism industry. To get a reliable forecast, it must be based on the principle of nature or the actual situation (Cui et al., 2013). However, finding the available natural principles is very difficult in physical and general systems (Lin et al., 2009). Therefore, taking forecasting from previous data observations is a practical alternative. To solve this problem, Deng proposed the grey system theory and captured the trend of systems development while focusing on insufficient knowledge and uncertainty (Deng, 1982). Grey system theory enables modeling with limited data and uncertainty (Liu \& Lin, 2006). Grey forecasting models are an important part of the grey system theory and have seen applications. All natural systems can be classified as grey systems as information in such systems is always insufficient (Esangbedo et al., 2021), including the tourism sector (Javed et al., 2020b). Therefore, the application of the grey forecasting model to forecast inbound tourism to Bali is a feasible step.

EGM $(1,1, \alpha, \theta)$ is a generalized form of the classical EGM $(1,1)$, and was proposed by Javed et al. (2020a). Its computational steps are as follows.

Let the actual data sequence be $x^{(0)}=\left(x^{(0)}(1), x^{(0)}(2), \ldots x^{(0)}(n)\right), x^{(0)}(k) \geq 0$, and the compatibility series of $x^{(0)}$ accumulated fractional data is $x^{(a)}=\left(x^{(a)}(1), x^{(a)}(2), \ldots x^{(a)}(n)\right)$ where, $x^{(a)}(k)=\sum_{i=1}^{k}\left(\frac{x^{(0)}(i)}{i^{1-a}}\right), k=1,2, \ldots, n$. The average sequence of neighbouring $x^{(1)}$ will be $z^{(1)}=$ $\left(z^{(1)}(1), z^{(1)}(2), \ldots z^{(1)}(n)\right)$. The Ordinary Least Square approach can be used to estimate parameters $a$ and $b$ and the time response function of the model is stated as

$$
\hat{x}^{(a)}(k)=\left(x^{(0)}(1)-\frac{b}{a}\right) e^{-a(k-1)}+\frac{b}{a} k=1,2, \ldots, n
$$

Inverted conformable fractional accumulation is required to extract the real $\hat{x}^{(0)}(k)$ data sequence simulation from the $\hat{x}^{(a)}(k)$ accumulated data sequence simulation is performed through the following regressive formulation

$$
\hat{x}^{(0)}(k)=k^{1-a}\left(\hat{x}^{(a)}(k)-\hat{x}^{(a)}(k-1)\right), k=1,2, \ldots, n ; \hat{x}^{(0)}(0)=0
$$

And the time-response function of $x^{(0)}$, which is an exponential function of time, is performed by 


$$
\hat{x}^{(0)}(k)=k^{1-a}\left(1-e^{a}\right)\left(x^{(0)}(1)-\frac{b}{a}\right) e^{-a(k-1)}, k=1,2, \ldots, n
$$

$\operatorname{EGM}(1,1, \alpha, \theta)$ has the advantage of being able to change parameters of $\alpha$ and $\theta$ with data variance as data noise can have various shapes. Contrary to the conventional model EGM $(1,1)$, the two parameters of the EGM model $(1,1, \alpha, \theta)$ are not static but dynamic and change their values as data noise varies, so that we generate relatively more precise forecasts. The complete detail on the model is available in Javed et al. (2020a).

\section{Research Methodology}

\subsection{Data Collection}

Data collection was conducted in Indonesia, and research was conducted entirely online. By examining various sources found and understanding the conditions and situation in Bali for visiting tourists. After collecting all the data, strategies and plans can provide predictions to develop Bali's tourism industry correctly. Data on "The Number of International Tourist Arrivals in Bali from 1997 to 2020" was obtained from Bali in Political Power and the Bali Provincial Statistics Agency, i.e., BPSPB (2020). Data for "The Financial Report for the Province of Bali 2019 Q1 to 2020 Q4" were obtained from Bank Indonesia on the website BI (2021). Data for "International Tourist Arrivals" in Bali in 2020 were obtained from BPSPB (2020). The "Actual Data" contained in the "Forecast Results of Tourist Visitors" was obtained from BPSPB (2020). "Revenue Data" on "Bali Tourism Revenue" was obtained from the World Tourism Organization, i.e., UNW'TO (2021).

\subsection{Forecasting techniques}

In the current study, the Even Grey Model EGM $(1,1, \alpha, \theta)$ was used to predict inbound tourists to Bali. For comparative analysis, Linear Regression (LR), Exponential Regression (ER), and Exponential Triple Smoothing (ETS) were run on Microsoft Excel. EGM $(1,1, \alpha, \theta)$ was built on the excel using the steps mentioned by Javed et al. (2020a).

\subsection{Measurement of Forecast Accuracy}

The most common summary indicator for assessing the accuracy of population forecasts is the mean absolute percent error (MAPE). Although MAPE has many desirable parameters, we argue that the widespread practice of exclusively using it to evaluate population forecasts should be modified, both normatively and relatively. MAPE is reported as a percentage and with the following formula.

$$
\operatorname{MAPE}(\%)=\frac{1}{n} \sum_{k=1}^{n}\left|\frac{x(k)-\hat{x}(k)}{\hat{x}(k)}\right| \times 100
$$

Here, $x(k)$ and $\hat{x}(k)$ are representing actual and the model-based data, respectively. The effectiveness of MAPE has been used in several studies, where prediction making using a grey model is involved. The use of the Lewis MAPE value scale is used to measure the accuracy of forecasts. This scale is given below (Javed et al., 2020b):

$$
\operatorname{MAPE}(\%)=\left\{\begin{array}{cr}
<10 & \text { Highly accurate forecast } \\
10-20 & \text { Good forecast } \\
20-50 & \text { Reasonable forecast } \\
>50 & \text { Inaccurate forecast }
\end{array}\right.
$$

\section{Results and discussion}

\subsection{Forecasting inbound tourists to Bali}

In the current study, a forecasting method is used to determine the number of tourist visitors who come to Bali to plan an increase in visits to increase the effectiveness and efficiency of implementing this strategy. For the forecasting, we used data from tourists visiting from 2009 to 2017. Data from 
Table 4. Forecasting of inbound tourists to Bali

\begin{tabular}{|c|c|c|c|c|c|}
\hline Year & $\begin{array}{c}\text { Actual } \\
\text { Data }\end{array}$ & $\begin{array}{c}\text { EGM } \\
(1,1, \alpha, \theta)\end{array}$ & $\begin{array}{c}\text { Linear } \\
\text { Regression }\end{array}$ & $\begin{array}{c}\text { Exponential } \\
\text { Regression }\end{array}$ & ETS \\
\hline 2009 & $2,385,122$ & $2,385,122$ & $2,091,236$ & $2,662,152$ & $2,562,216$ \\
\hline 2010 & $2,576,142$ & $2,363,454$ & $2,451,094$ & $2,940,368$ & $2,922,318$ \\
\hline 2011 & $2,822,670$ & $2,640,191$ & $2,810,952$ & $3,247,660$ & $3,282,420$ \\
\hline 2012 & $2,949,332$ & $2,949,332$ & $3,170,810$ & $3,587,067$ & $3,642,522$ \\
\hline 2013 & $3,278,598$ & $3,294,670$ & $3,530,668$ & $3,961,944$ & $4,002,624$ \\
\hline 2014 & $3,766,638$ & $3,680,444$ & $3,890,526$ & $4,375,999$ & $4,362,726$ \\
\hline 2015 & $4,001,835$ & $4,111,388$ & $4,250,384$ & $4,833,326$ & $4,722,828$ \\
\hline 2016 & $4,297,937$ & $4,592,791$ & $4,610,243$ & $5,338,447$ & $5,082,930$ \\
\hline 2017 & $5,697,739$ & $5,130,562$ & $4,970,101$ & $5,896,358$ & $5,443,032$ \\
\hline 2018 & $6,070,473$ & $5,731,301$ & $5,329,959$ & $6,512,574$ & $5,803,134$ \\
\hline 2019 & $6,275,210$ & $6,402,380$ & $5,689,817$ & $7,193,191$ & $6,163,236$ \\
\hline 2020 & & $7,152,037$ & $6,049,675$ & $7,944,937$ & $6,523,338$ \\
\hline 2021 & & $7,989,470$ & $6,409,533$ & $8,775,246$ & $6,883,440$ \\
\hline 2022 & & $8,924,959$ & $6,769,391$ & $9,692,330$ & $7,243,542$ \\
\hline 2023 & & $9,969,985$ & $7,129,250$ & $10,705,256$ & $7,603,644$ \\
\hline 2024 & & $11,137,373$ & $7,489,108$ & $11,824,041$ & $7,963,746$ \\
\hline 2025 & & $12,441,451$ & $7,848,966$ & $13,059,748$ & $8,323,848$ \\
\hline $\begin{array}{c}\text { MAPE\% } \\
\text { (in-sample) } \\
(2009-2017)\end{array}$ & & $4.63 \%$ & $6.93 \%$ & $16.44 \%$ & $15.48 \%$ \\
\hline $\begin{array}{c}\text { MAPE } \% \\
\text { (out-of-sample) } \\
\text { (2018-2019) }\end{array}$ & & $3.81 \%$ & $10.76 \%$ & $10.96 \%$ & $3.09 \%$ \\
\hline
\end{tabular}

2018 to 2019 was used for out-of-sample testing. To ensure accuracy, we use mean absolute percentage error (MAPE).

Based on data analysis from four forecasting methods, the EGM $(1,1, \alpha, \theta)$ showed the highest accuracy in both in-sample and out-sample testing in determining the income and losses of the tourism industry in Bali. In-sample is the data we use for forecasting, and out-of-sample is the data we don't use for forecasting but use to see whether our forecast is matching with it (reality) or not. According to the Lewis scale, a forecast error of less than $10 \%$ shows a highly accurate forecast. Hence, EGM $(1,1, \alpha, \theta)$ is comparatively most accurate. The results are shown in Table 4 and Figure 1. With more than $95 \%$ accuracy, the grey forecasting revealed that 7,152,037 (7.2 million) tourists were expected in 2020 but due to the pandemic only 1,069,473 (1.07 million) visited. Thus, this gap can be used to quantify the financial losses that Bali incurred as a result of fall in revenue per tourist. In the succeeding section the financial losses will be estimated.

\subsection{Bali's financial loss due to the COVID-19 outbreak}

The COVID-19 pandemic that occurred in Bali greatly impacted the economy in the tourism industry. Many tourist attractions cannot operate due to the absence of tourists who wish to visit, especially foreign tourists who have not entered the Bali area. This is a loss to the income of the tourism industry in Bali.

The data presented in Table 5 shows that revenue per tourist to Indonesia increased from $\$ 1090$ in 2016 to $\$ 1142$ in 2019 . Hence, in 2020 it was likely to be more than $\$ 1142$. Let's assume it to be $\$ 1142$ in 2020 (though the real value is expected to be greater than it). We presume this increasing trend holds for Bali as well. Meanwhile, because of the COVID-19 outbreak in Bali, the actual revenue was $\$ 807$. The forecasting model revealed to us that 7,152,037 tourists were expected to visit Bali in 2020. Let's assume the revenue per tourist to Bali in 2020 is equal to the average revenue per tourist to Indonesia in 2020. Therefore, the estimated expected revenue in 2020 from inbound tourism, denoted by R (2020), is calculated as 


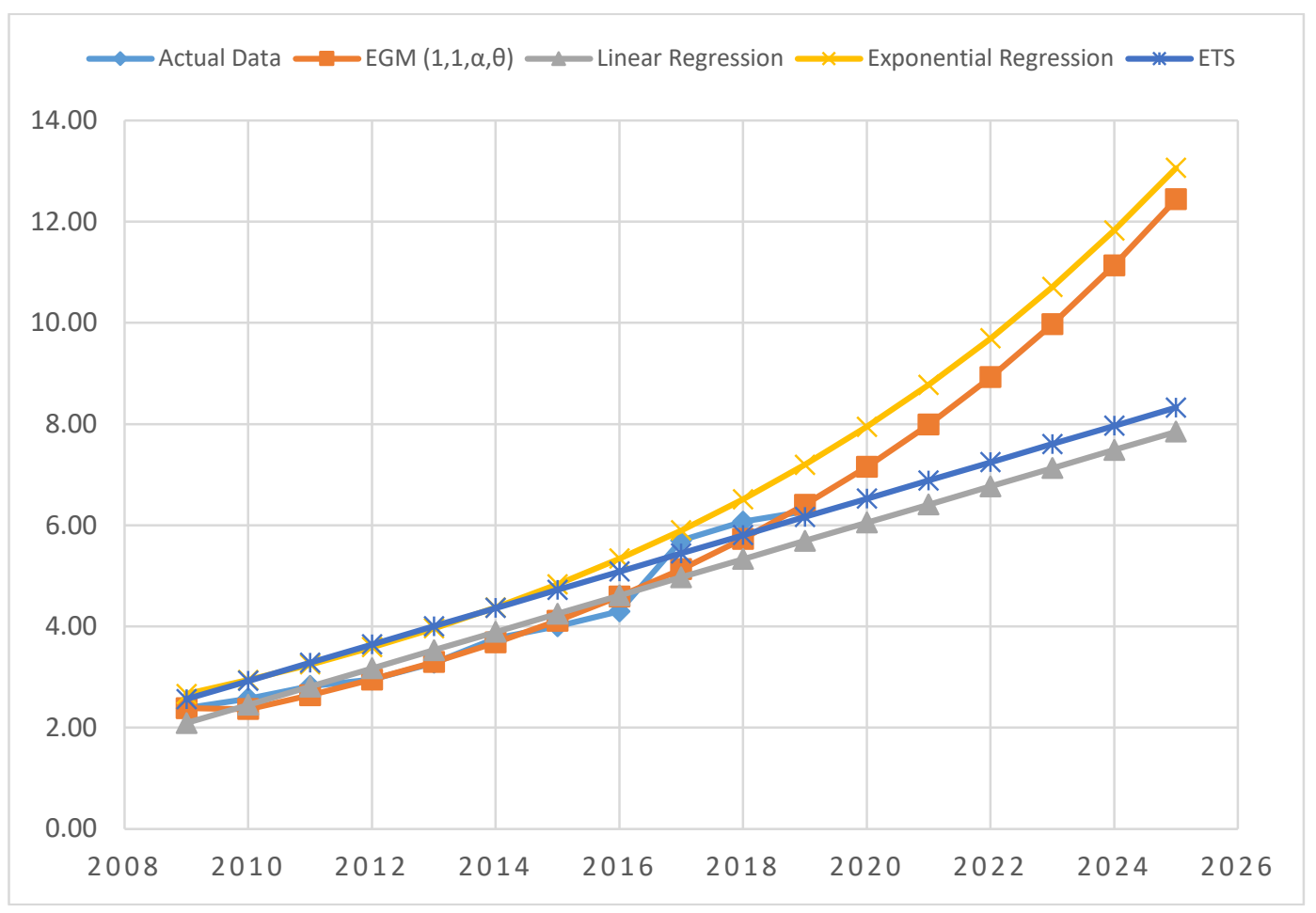

Figure 1. Forecast of inbound tourists (in millions) to Bali till 2025

The tourism sector plays a vital role in the economy of Bali. Bali should have an income of around $\$ 8,167,626,254$ in 2020, but due to the COVID-19 pandemic in 2020, Bali's income is just $\$ 863,027,466$. Bali's estimated financial loss due to COVID-19 in 2020, denoted as B (2020), can be,

$$
\text { B (2020): \$ 863,027,466 - \$8,167,626,254 = -\$7,304,598,788 }
$$

Thus, Bali incurred an estimated loss of over $\$ 7.3$ billion. Considering the increase in revenue per tourist, a trend that was reversed by the pandemic, one can argue that this value is an optimistic estimate as the real loss is likely to be higher. The prolonging of the fight against the pandemic will only increase losses as using a similar methodology, losses can be estimated for the year 2021 as well if the world failed to contain the virus by the end of the year.

\subsection{Discussion}

Based on the data that has been discussed in the previous chapter, the ability to adapt to the current situation is very influential on the tourism industry. This is because the current situation influences the tourism industry. That way, entrepreneurs involved in and participate in the tourism industry can survive in any condition. It can be seen from the data of tourists who visited Bali when the COVID-19 pandemic hit them. There are step-by-step increases that have occurred. There was an increase after business actors participated in government regulations. It can be seen that after the government sets rules for the tourism industry, namely the CHSE, business actors who are ready for these provisions will have a positive impact on their business. Business actors who continue to invest in advertising in the tourism industry will have a good effect, especially after the pandemic ends and holidays arrive.

Table 5. Inbound Tourism in Indonesia

\begin{tabular}{|l|c|c|c|}
\hline Year & Number of Tourists in Indonesia $^{\mathbf{1}}$ & Indonesia's Revenue (\$) $^{\mathbf{1}}$ & Revenue per tourist (\$) $^{\mathbf{2}}$ \\
\hline 2016 & $11,520,000$ & $12,566,000,000$ & 1091 \\
\hline 2017 & $14,040,000$ & $14,692,000,000$ & 1046 \\
\hline 2018 & $15,810,000$ & $17,915,000,000$ & 1133 \\
\hline 2019 & $16,110,000$ & $18,404,000,000$ & 1142 \\
\hline 2020 & $4,020,000$ & $3,244,000,000$ & 807 \\
\hline
\end{tabular}


Many things must be done to keep fighting and survive the demanding conditions that affect income and the economy. Continue to constantly develop in management and planning and strategies that will help revenue and visiting tourists. Managing a business also requires a lot of experience and knowledge. A lot of experience, expertise, and accuracy can help decide strategy and plan for the future (Linnenluecke et al., 2012). By following some suggestions in managing the tourism business and implementing it, it is hoped that it can help the economy in the tourism industry, which looks like the COVID-19 pandemic. The increase in the tourism industry in Bali must be driven by investment in management so that planning and management can develop properly. A competent workforce shows an industry's competitiveness in dealing with disasters and crises that can immediately help recovery from ongoing changes (Wang et al., 2020).

\section{Conclusion and recommendations}

The findings of this study provide insight into information that can help small and medium enterprises and Tour \& Travel service providers affected by the COVID-19 pandemic. Small and medium entrepreneurs and Tour \& Travels service providers can appropriately adapt to the current situation and plan and improve it. Furthermore can affect the increase in tourists visiting Bali. Improving infrastructure, hospitality, and security can potentially impact increasing tourists and lead to better income. It is hoped that the COVID-19 pandemic will end soon, and the spread of the virus will not happen again, and the economy in the tourism industry sector will run normally. Also, some recommendations can be made at this stage, which are listed below.

\subsection{Change the paradigm of advertisement}

Advertising tourism with the concept of "hard selling" is no longer an option in this unfavorable situation. The number of people who want to travel and take vacations has decreased. Therefore, the concept of advertising with "soft selling" can be an option. Soft selling is advertising in displaying brands and brands in a subtle and non-aggressive manner. Soft selling is designed to avoid customers feeling pressured by heavy advertising. Soft selling is also a technique in persuasive and subtle selling. Techniques such as soft selling may not significantly impact the beginning of advertising but will eventually help drive continuous sales in the next period (Kenton, 2019). The use of soft selling in the tourism industry can influence the introduction of tourism itself. This can introduce the tourism industry and the tourist attractions themselves to various circles. With soft selling, people will be able to recognize and make a holiday wishlist for the future when the situation has started to improve from the conditions of the COVID-19 pandemic. This could have a significant impact in the future.

\subsection{Develop new business models}

Tourism entrepreneurs must also adjust to the current situation, seeing the changing habits of tourists. Activities in the tourism industry must also be able to follow market needs. In this case, it can be in the form of tours and trips. Changing travel schedules more flexibly and visiting more beautiful tourist attractions can be an option. Supported by Bali's friendly and relaxed nature, travel in Bali can focus more on outdoor tourism. One of the visits that can be an option for tour \& travel entrepreneurs is to visit to enjoy views of rice fields and mountains. The tourism industry in Bali can also change the concept from indoor to outdoor. Where the air circulation is smoother, and visitors feel the cool breeze. This is to avoid spreading the virus because, in a closed room, the virus will spread more easily. Restaurants or cafes can adapt this concept. Business actors can give tourists a discount for each vacation visit and a gift from each completed tour in financial management. This will provide them with a good image in traveling.

\subsection{Improving quality control}

Quality control on visitors must also be closely monitored, starting from tourist trips using public transportation or private transportation. Before traveling, it is mandatory always to check health and test PCR for COVID-19. Supervision of visitors can also be captured and spread in the media. This can provide a good perspective in the community where people will feel more secure and visit. Advertising reasonable and correct quality control can also be an example for other industries related to the tourism 
industry. With this, it will improve the economy after the impact of the COVID-19 pandemic. Also, the vaccination rate should be improved to ensure the long-lasting success of other initiatives.

\section{References}

Abu-Eisheh, S. A., \& Mannering, F. L.(2010). Forecasting Automobile Demand for Economies in Transition: A Dynamic Simultaneous-Equation System Approach. Transportation Planning and Technology, 25(4), 311-331. https://doi.org/10.1080/0308106022000019026.

Beirman, D. (2017). Bali tourism and the Mt Agung volcano: Quick dollars or long-term reputation. The Conversation. Available at https://theconversation.com/bali-tourism-and-the-mt-agung-volcano-quickdollars-or-long-term-reputation-88322

Bhaskara, G. I., \& Filimonau, V. (2021). The COVID-19 pandemic and organizational learning for disaster planning and management: A perspective of tourism businesses from a destination prone to consecutive disasters. Journal of Hospitality and Tourism Management, 46, 364-375. https://doi.org/10.1016/j.jhtm.2021.01.011

BI (2021) The Central Bank of Indonesia (Bank Sentral Republik Indonesia) Available at https://www.bi.go.id/id/publikasi/laporan/lpp/Pages/Laporan-Perekonomian-Provinsi-Bali-Februari2021.aspx

Blackman, D., \& Ritchie, B. W. (2009). Tourism Crisis Management and Organizational Learning. Journal of Travel \& Tourism Marketing, 23(2-4), 45-57. https://doi.org/10.1300/J073v23n02_04

BPSPB. (2020). Statistics of Bali Province (Badan Pusat Statistik Provinsi Bali). BPS. Available from https://bali.bps.go.id/indicator/16/106/1/banyaknya-wisatawan-mancanegara-bulanan-ke-bali-menurutpintu-masuk.html

Cioccio, L., \& Michael, E. J. (2007). Hazard or disaster: Tourism management for the inevitable in Northeast Victoria. Tourism Management, 28(1), 1-11. https://doi.org/10.1016/j.tourman.2005.07.015

COVID-19 Dashboard by the Center for Systems Science and Engineering (CSSE) at Johns Hopkins University (JHU). Available

https://www.arcgis.com/apps/opsdashboard/index.html\#/bda7594740fd40299423467b48e9ecf6

Cui, J., Liu, S. F., Zeng, B., \& Xie, N. M. (2013). A novel grey forecasting model and its optimization. Applied Mathematical Modelling, 37(6), 4399-4406. https://doi.org/10.1016/j.apm.2012.09.052

Deng, J. (1982). Control problems of grey systems. Systems \& Control Letters, 1 (5), 288-294. https://doi.org/10.1016/S0167-6911(82)80025-X

Esangbedo, M. O., Bai, S., Mirjalili, S., \& Wang, Z. (2021). Evaluation of human resource information systems using grey ordinal pairwise comparison MCDM methods. Expert Systems With Applications, 182, 115151. https://doi.org/10.1016/j.eswa.2021.115151

Filimonau, V., \& De Coteau, D. (2020). Tourism resilience in the context of integrated destination and disaster management (DM2). International Journal of Tourism Research, 22(2), 202-222. https://doi.org/10.1002/jtr.2329

Ghaderi, Z., Mat Som, A. P., \& Henderson, J. C. (2015). When disaster strikes: The Thai floods of 2011 and tourism industry response and resilience. Asia Pacific Journal of Tourism Research, 20(4), 399-415. https://doi.org/10.1080/10941665.2014.889726

Hall, C. M., \& Prayag, G. (2020). Tourism and earthquakes - aspects of tourism. Bristol: Channel View Publications. https://doi.org/10.21832/HALL7864

Hall, C. M., Malinen, S., Vosslamber, R., \& Wordsworth, R. (Eds.). (2016). Business and post-disaster management: Business, organizational and consumer resilience and the Christchurch earthquakes. Routledge. https://doi.org/10.4324/9781315640211

Haryanto, T. (2020). COVID-19 pandemic and international tourism demand. Journal of Developing Economies, 5(1), 1-5.

Hitchcock, M., \& Putra, N. D. (2005). The Bali bombings: Tourism crisis management and conflict avoidance. Current Issues in Tourism, 8(1), 62-76.

Irfan, M., Ikram, M., Ahmad, M., Wu, H., \& Hao, Y. (2021). Does temperature matter for COVID-19 transmissibility? Evidence across Pakistani provinces. Environmental Science and Pollution Research. https://doi.org/10.1007/s11356-021-14875-6

Javed, S. A., Ikram, M., Tao, L., \& Liu, S. (2020b). Forecasting key indicators of China's inbound and outbound tourism: optimistic-pessimistic method. Grey Systems: Theory and Application. https://doi.org/10.1108/GS12-2019-0064

Javed, S. A., Zhu, B., \& Liu S. (2020a). Forecast of Biofuel Production and Consumption in Top $\mathrm{CO}_{2}$ Emitting Countries using a novel grey model. Journal of Cleaner Production, 276, 123977. DOI:10.1016/j.jclepro.2020.123997 
Jiang, Y., \& Ritchie, B. W. (2017). Disaster collaboration in tourism: Motives, impediments and success factors. Journal of Hospitality and Tourism Management, 31, 70-82. https://doi.org/10.1016/j.jhtm.2016.09.004

Kemenparekraf (2020). Ministry of Tourism and Creative Economy. Available at https://chse.kemenparekraf.go.id

Lin, Y. H., Lee, P. C., \& Chang, T. P. (2009). Adaptive and high-precision grey forecasting model. Expert Systems with Applications, 36(6), 9658-9662. https://doi.org/10.1016/j.eswa.2008.12.009

Linnenluecke, M. K., Griffiths, A., \& Winn, M. (2012). Extreme weather events and the critical importance of anticipatory adaptation and organizational resilience in responding to impacts. Business Strategy and the Environment, 21, 17-32. https://doi.org/10.5465/AMBPP.2012.14790

Liu, S., \& Lin, Y. (2006). Grey information: theory and practical applications. Springer Science \& Business Media.

Mahmoudi, A., Javed, S. A., \& Mardani, A. (2021). Gresilient Supplier Selection through Fuzzy Ordinal Priority Approach: Decision-making in Post-COVID era. Operations Management Research. https://doi.org/10.1007/s12063-021-00178-z

Putra, I. N. D. (2008). Bali in Political Power [Bali dalam kuasa politik]. Available at https://www.academia.edu/27071381/Bali_dalam_Kuasa_Politik

Seraphin, H. (2019). Natural disaster and destination management: The case of the Caribbean and hurricane Irma. Current Issues in Tourism, 22 (1), 21-28. https://doi.org/10.1080/13683500.2017.1422483

Silvita A. (2019). 15 Best Islands in the World 2019, Bali What is the Ranke? [15 Pulau Terbaik di Dunia 2019, Bali Peringkat Berapa?]. Kompas. https://travel.kompas.com/read/2019/07/11/080300727/15-pulauterbaik-di-dunia-2019-bali-peringkat-berapa-

UNWTO. (2021). The World Tourism Organization. Available from https://www.unwto.org/global-andregional-tourism-performance.

Wang, K., Yang, H., \& Zhang, A. (2020). Seaport adaptation to climate change-related disasters: terminal operator market structure and inter-and intra-port coopetition. Spatial Economic Analysis, 15(3), 311-335. https://doi.org/10.1080/17421772.2019.1708443.

Yamashita, S. (2012). Gema Perdamaian: Tourism, religion, and peace in multicultural Bali. Jurnal Kajian Bali, 2(2), 165-181. Available at https://core.ac.uk/display/89142972 